\section{BMJ Open} Ophthalmology

\title{
Phenotype of Coats disease in females
}

\author{
Alejandra Daruich (D) , ${ }^{1}$ Francis L Munier ${ }^{2}$
}

To cite: Daruich A, Munier FL. Phenotype of Coats disease in females. BMJ Open Ophthalmology 2022;7:e000883. doi:10.1136/ bmjophth-2021-000883

Received 24 August 2021 Accepted 18 January 2022

\section{Check for updates}

\section{(C) Author(s) (or their} employer(s)) 2022. Re-use permitted under CC BY-NC. No commercial re-use. See rights and permissions. Published by BMJ.

${ }^{1}$ Ophthalmology Department, Hôpital Necker-Enfants Malades, AP-HP, Université de Paris, Paris. INSERM, Centre de Recherche des Cordeliers, Team 17, Paris, France

${ }^{2}$ Ophthalmology Department, University of Lausanne, JulesGonin Eye Hospital, Fondation Asile des Aveugles, Lausanne, Switzerland

Correspondence to Dr Francis L Munier; francis. munier@fa2.ch

\section{ABSTRACT}

Objective To determine whether the clinical presentation of Coats disease differs between males and females. Methods and analysis Records of patients diagnosed with Coats disease at a single institution were retrospectively reviewed. Demographic data, main reason for initial consultation, comprehensive ocular examination at diagnosis and modalities of treatments during the follow-up were recorded.

Results Records from 114 patients with Coats disease were analysed. Ninety-eight patients (86\%) were male and $16(14 \%)$ female. Mean age at diagnosis was 6.2 years \pm 6.1 in males and 7.4 years \pm 4.7 in females. The main initial reason for consultation was strabismus in males and decreased visual acuity in females. Stage severity at diagnosis was similar in the two groups with half of the patients presenting with stage 2B2 or lower. The extension of peripheral retinal telangiectasia was also similar (mean: $6.2 \pm 3.4$ and 5.8 \pm 4.0 , respectively), as was the extension of intraretinal exudation (mean: $5.0 \pm 4.5$ and $5.8 \pm 4.4$ ) and the frequency of a subfoveal nodule at diagnosis ( $40 \%$ vs $30 \%$, respectively). There was no distinction between the number of laser photocoagulation or cryotherapy sessions required for both groups during the follow-up.

Conclusions Coats disease presentation does not differ between genders despite being much rarer in females. We propose a pathogenic mechanism accounting for the gender-dependent incidence combined with genderindependent expressivity of Coats disease.

\section{INTRODUCTION}

Coats disease was first described by Coats. ${ }^{1}$ This congenital condition is characterised by unilateral peripheral retinal telangiectasia and exudation without retinal or vitreal traction, at least at presentation. ${ }^{2}$ Coats disease is sporadic without associated systemic findings and usually diagnosed in the first decade of life. Younger age at presentation has been associated with a more severe phenotype. ${ }^{34}$

Coats disease predominately affects males, with about $15 \%$ of cases affecting females. $^{3} 5$ Male gender predilection remains unexplained since the aetiology and pathogenesis of Coats disease is still not completely understood. ${ }^{6}$ Black et al investigated the potential role of the X-linked NDP gene by mutational screening of nine enucleated eyes from males with Coats disease and found a somatic mutation in one of them, which was absent in non-retinal tissue.

\section{Key messages}

What is already known about this subject?

Coats disease predominately affects males, with about $15 \%$ of cases affecting females. Male gender predilection remains unexplained since the aetiology and pathogenesis of Coats disease is still not completely understood. There is no description of the phenotypic features of Coats disease in females.

\section{What are the new findings?}

Coats disease presentation does not differ between genders despite being much rarer in females.

How might these results change the focus of research or clinical practice?

- Based on these clinical finding, we propose a pathogenic mechanism accounting for the genderdependent incidence combined to the genderindependent expressivity of Coats disease. Further molecular studies should explore this hypothesis.

This observation supported the hypothesis that telangiectasia in Coats disease could be secondary to a norrin deficiency at the cellular level in the corresponding developing retinal segment, explaining the unilateral mosaic phenotypic expressivity as well as the sporadic non-hereditary nature of the disease. ${ }^{7}$ According to these authors, the relative non-penetrance in females could be further explained by skewed lyonization preferentially inactivating the X-chromosome carrying the mutant NDP allele and thus maintaining 'physiological' levels of norrin expression in the mutated retina. Inversely, when skewed lyonization preferentially inactivates the X-chromosome carrying the normal NDP allele, the level of norrin expression may be suppressed deeply enough in the mutated retinal segment that clinical Coats phenotype is seen. However, according to this hypothesis nothing can be predicted regarding the phenotypic expressivity in females or how this expressivity compares with males. Surprisingly, there is virtually no description in the literature of the phenotypic features of Coats disease in females. The aim of this study is to determine whether the clinical presentation of Coats disease differs between males and females. 


\section{METHODS}

\section{Subjects}

Records of patients diagnosed with Coats disease between August 1989 and February 2021 at a single institution (Jules-Gonin Eye Hospital, Lausanne, Switzerland) were retrospectively reviewed. Patients or the public were not involved in the design, or conduct, or reporting, or dissemination plans of our research.

Demographic data, main reason for initial consultation and comprehensive ocular examination were recorded at diagnosis. Coats disease was classified according to Shields $e t$ $a l^{8}$ and Daruich $e t a t^{\imath}$ into stage 1, telangiectasia only; stage 2, telangiectasia and exudation (2A, extrafoveal exudation; 2B1, foveal exudation without subfoveal nodule; 2B2, with subfoveal nodule); stage 3, exudative retinal detachment (3A1, extrafoveal subtotal retinal detachment; 3A2, foveal subtotal retinal detachment; 3B, total retinal detachment); stage 4 , total detachment and secondary glaucoma and stage 5, advanced end-stage disease. Colour fundus photographs were performed with RetCam I and II (Clarity Medical Systems, Pleasanton, California, USA), Optos 200 Tx (Optos, Dunfermline, UK) and Panoret-1000 (CMT Medical Technologies, Valley Stream, New York, USA). Fluorescein angiography was performed with RetCam I and II and Optos 200 Tx. The extension of peripheral telangiectasia on FA and intraretinal exudation on colour fundus photographs at presentation were quantified in terms of clock hours, from 1 to 12 . Among patients presenting with stage $3 \mathrm{~A} 1$ or lower, the presence of a subfoveal nodule at presentation as previously described ${ }^{9}$ was recorded. The modality of treatment (laser photocoagulation, cryotherapy, anti-VEGF therapy, and surgery) was recorded as well as the number of laser or cryotherapy sessions received by each patient.

\section{Statistical analysis}

Comparative statistics (using Mann-Whitney, $\chi^{2}$ or Fisher's exact test where appropriate) was performed on GraphPad Prism (V.9.1.0, GraphPad Software, La Jolla, California, USA). In all statistical comparisons, differences with a $p$ value inferior to 0.05 were considered significant.

\section{RESULTS}

Records from 114 patients with Coats disease were analysed. Table 1 summarises the comparative clinical findings between male and female patients with Coats disease. Ninety-eight patients $(86 \%)$ were males and 16 females $(14 \%)$. Mean age at diagnosis was 6.2 years \pm 6.1 in males and 7.4 years \pm 4.7 in females $(\mathrm{p}=0.2)$. The main initial reason for consultation was strabismus $(n=33 / 98,34 \%$ of cases) in male and decreased visual acuity in female patients ( $n=6 / 16,38 \%$ of cases), both symptoms being the most frequently reported overall with $59 \% \quad(n=57 / 98)$ and $69 \%(\mathrm{n}=11 / 16)$ of cases, respectively. Stage severity at diagnosis was similar between groups $(\mathrm{p}=0.6)$, with about half of patients presenting with stage 2B2 or lower in both groups. Extension of peripheral retinal telangiectasia was alike between males and females (mean \pm SD: $6.2 \pm 3.4$ and

\begin{tabular}{|c|c|c|c|}
\hline & Males & Females & $P$ value \\
\hline Patients, N (\%) & $98(86)$ & $16(14)$ & \\
\hline Mean age at diagnosis (years) & $6.2 \pm 6.1$ & $7.4 \pm 4.7$ & 0.2 \\
\hline \multicolumn{4}{|l|}{ First symptom, N (\%) } \\
\hline Decreased visual acuity & $24(25)$ & $6(38)$ & 0.5 \\
\hline Strabismus & $33(34)$ & $5(31)$ & \\
\hline Leukocoria & $17(17)$ & $2(13)$ & \\
\hline No symptom & $17(17)$ & $2(13)$ & \\
\hline NA & $7(7)$ & $1(6)$ & \\
\hline \multicolumn{4}{|l|}{ Stage, N (\%) } \\
\hline$\leq 2 \mathrm{~B} 2$ & $50(51)$ & $9(56)$ & 0.6 \\
\hline$>2 \mathrm{~B} 2$ & $48(49)$ & $7(44)$ & \\
\hline $\begin{array}{l}\text { Telangiectasia extension (clock } \\
\text { hours, mean } \pm \text { SD) }\end{array}$ & $6.2 \pm 3.4$ & $5.8 \pm 4.0$ & 0.6 \\
\hline $\begin{array}{l}\text { Intraretinal exudation extension } \\
\text { (clock hours, mean } \pm \text { SD) }\end{array}$ & $5.0 \pm 4.5$ & $5.8 \pm 4.4$ & 0.5 \\
\hline $\begin{array}{l}\text { Subfoveal nodule at diagnosis, } \\
\mathrm{N}(\%)\end{array}$ & $26 / 63(40)$ & $3 / 10(30)$ & 0.7 \\
\hline $\begin{array}{l}\text { No of laser photocoagulation } \\
\text { and/or cryotherapy sessions, } \mathrm{N}\end{array}$ & $5.0 \pm 2.7$ & $3.7 \pm 2.8$ & 0.1 \\
\hline $\begin{array}{l}\text { Mean follow-up (years, } \\
\text { mean } \pm S D \text { ) }\end{array}$ & $4.6 \pm 4.6$ & $5.1 \pm 5.8$ & 0.8 \\
\hline
\end{tabular}

*Among patients with stage $3 A 1$ or less at diagnosis.

$\mathrm{NA}$, not available.

$5.8 \pm 4.0$, respectively), as well as the extension of peripheral intraretinal exudation (mean \pm SD: $5.0 \pm 4.5$ and $5.8 \pm 4.4$, respectively). Among patients presenting with stage $3 \mathrm{~A} 1$ or lower, the frequency of a subfoveal nodule at diagnosis was similar between males and females $(\mathrm{n}=26 / 63(40 \%)$ and $\mathrm{n}=3 / 10(30 \%)$, respectively, $(\mathrm{p}=0.7)$. Finally, among patients treated by laser photocoagulation or cryotherapy, the mean number of sessions performed was similar for males and females during follow-up, with a mean of $5.0 \pm 2.7$ and $3.7 \pm 2.8$ sessions, respectively $(\mathrm{p}=0.1)$.

\section{DISCUSSION}

This study demonstrates that the clinical presentation of Coats disease is similar in both male and female patients. Although Coats disease has a clear male gender predilection, age at presentation and severity of the disease did not show differences linked to gender.

Females represent $14 \%$ of cases in this cohort, as previously reported. ${ }^{25}$ According to our findings, Coats phenotypes in males and females cannot be distinguished in terms of age of onset or retinal expressivity, but differ only in their incidence characterised by a sex ratio of 8.6 males for 1.4 females.

Coats disease was tentatively attributed to NDP somatic mutations affecting males preferentially and females only secondary to a skewed NDP X-inactivation of the wildtype copy. ${ }^{7}$ However, this theory postulates that the NDP gene belongs to the $75 \% \mathrm{X}$-linked genes undergoing X-inactivation, ${ }^{10}$ which remains a presumption since 
NDP inactivation status has not yet been determined in humans. ${ }^{11}$ The theory is further challenged by the fact that the presumed underlying mechanism would rather predict a milder mean phenotype in females rather than an identical gender-independent expressivity. ${ }^{12}$

To reconcile the theory with our observation requires an additional hypothesis, namely a threshold effect linked to whether tissue norrin levels are sufficient or not to prevent the Coats phenotype (on/off phenomenon). This threshold effect could be determined by the compensatory effect of the norrin-competent islands on their neighbouring norrin-incompetent ones by diffusion of secreted norrin protein. ${ }^{13}$ In turn, this compensatory mechanism presupposes a fine-grained X-inactivation retinal mosaicism, compatible with the diffusion distance of norrin, such as the one seen in heterozygote carriers of X-linked $\mathrm{RP}^{14}$ or of ocular albinism. ${ }^{15}$ In this setting of superposing two levels of mosaicism (NDP mutated sector with a background X-inactivation fine-grained mosaic), only skewed NDP inactivation towards activity of the normal allele, depressing norrin below the threshold level, would cause full blown Coats phenotype in the mutated mosaic territory, while in all other circumstances the remaining norrin levels would completely silence the expression of the Coats phenotype rescuing the genotypically mutant retina.

Limitations of this study include its retrospective nature and the small number of cases in the female group due to the rare incidence of Coats disease in female patients. Further studies would benefit from larger cohorts and exploration of underlying molecular mechanisms, particularly presence and nature of NDP mutation in retinal tissue and the level of protein expression. Additionally, evidence of NDP X- inactivation and the degree of $\mathrm{X}$-chromosome inactivation in affected females should be further explored.

In conclusion, Coats disease is rare in female patients but its clinical presentation does not differ from that of males. Further studies are needed to explore the underlying molecular mechanisms of these clinical findings.

Acknowledgements The authors would like to thank Sue Houghton for English revision of manuscript.

Contributors AD: acquisition of data, analysis and interpretation of data, drafting manuscript. FM: conception and design, analysis and interpretation of data, critical revision of manuscript and guarantor, responsible for the overall content of the manuscript.

Funding The authors have not declared a specific grant for this research from any funding agency in the public, commercial or not-for-profit sectors.

Competing interests None declared.

Patient and public involvement Patients and/or the public were not involved in the design, or conduct, or reporting, or dissemination plans of this research.
Patient consent for publication Not applicable.

Ethics approval This retrospective study was designed in accordance with the tenets of the Declaration of Helsinki, and was approved by the Ethics Committee of the Swiss Federal Department of Health (CER-VD no 95/15).

Provenance and peer review Not commissioned; externally peer reviewed.

Data availability statement Data sharing not applicable as no datasets generated and/or analysed for this study. Data are available on reasonable request.

Open access This is an open access article distributed in accordance with the Creative Commons Attribution Non Commercial (CC BY-NC 4.0) license, which permits others to distribute, remix, adapt, build upon this work non-commercially, and license their derivative works on different terms, provided the original work is properly cited, appropriate credit is given, any changes made indicated, and the use is non-commercial. See: http://creativecommons.org/licenses/by-nc/4.0/.

ORCID iD

Alejandra Daruich http://orcid.org/0000-0001-7907-4325

\section{REFERENCES}

1 Coats G. Forms of retinal diseases with massive exudation. Roy Lond Ophthalmol Hosp Rep 1908:440-525 https://scholar.google. com/scholar_lookup?journal=Roy+Lond+Ophthalmol+Hosp+Rep\& title=Forms+of+retinal+diseases+with+massive+exudation\&author= $\mathrm{G}+$ Coats\&volume $=17$ \&publication_year $=1908$ \&pages $=440-525 \&$

2 Shields JA, Shields CL, Honavar SG, et al. Clinical variations and complications of coats disease in 150 cases: the 2000 Sanford Gifford memorial lecture. Am J Ophthalmol 2001;131:561-71.

3 Daruich A, Matet A, Munier FL. Younger age at presentation in children with coats disease is associated with more advanced stage and worse visual prognosis: a retrospective study. Retina 2018;38:2239-46.

4 Dalvin LA, Udyaver S, Lim L-AS, et al. Coats disease: clinical features and outcomes by age category in 351 cases. J Pediatr Ophthalmol Strabismus 2019;56:288-96.

5 Shields CL, Udyaver S, Dalvin LA, et al. Coats disease in 351 eyes: analysis of features and outcomes over 45 years (by decade) at a single center. Indian J Ophthalmol 2019;67:772-83.

6 Sen M, Shields CL, Honavar SG, et al. Coats disease: an overview of classification, management and outcomes. Indian J Ophthalmol 2019;67:763-71.

7 Black GC, Perveen R, Bonshek R, et al. Coats' disease of the retina (unilateral retinal telangiectasis) caused by somatic mutation in the NDP gene: a role for norrin in retinal angiogenesis. Hum Mol Genet 1999;8:2031-5.

8 Shields JA, Shields CL, Honavar SG, et al. Classification and management of coats disease: the 2000 Proctor lecture. Am J Ophthalmol 2001;131:572-83.

9 Daruich A, Moulin AP, Tran HV. Subfoveal nodule in coats disease: towards an updated classification predicting visual prognosis. Retina 2017;37.

10 Carrel L, Willard HF. X-inactivation profile reveals extensive variability in X-linked gene expression in females. Nature 2005;434:400-4.

11 Fahim AT, Daiger SP. The role of X-chromosome inactivation in retinal development and disease. Adv Exp Med Biol 2016;854:325-31.

12 Fahim AT, Sullivan LS, Bowne SJ, et al. X-Chromosome inactivation is a biomarker of clinical severity in female carriers of RPGRassociated X-linked retinitis pigmentosa. Ophthalmol Retina 2020;4:510-20.

13 Ohlmann A, Tamm ER. Norrin: molecular and functional properties of an angiogenic and neuroprotective growth factor. Prog Retin Eye Res 2012;31:243-57.

14 Cideciyan AV, Jacobson SG. Image analysis of the tapetal-like reflex in carriers of X-linked retinitis pigmentosa. Invest Ophthalmol Vis Sci 1994;35:3812-24.

15 De Silva SR, Arno G, Robson AG, et al. The X-linked retinopathies: physiological insights, pathogenic mechanisms, phenotypic features and novel therapies. Prog Retin Eye Res 2021;82:100898. 